\title{
Effects of fertilizer and biochar applications on the relationship among soil moisture, temperature, and $\mathrm{N}_{2} \mathrm{O}$ emissions in farmland
}

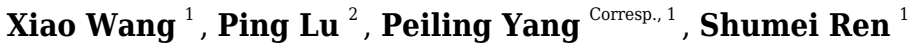 \\ ${ }^{1}$ College of Water Resources and Civil Engineering, China Agricultural University, Beijing, China \\ ${ }^{2}$ College of Sericulture, Textile and Biomass Sciences, Southwest University, Chongqing, China \\ Corresponding Author: Peiling Yang \\ Email address: cau_yangpeiling@163.com
}

Background. Di-nitrogen oxide $\left(\mathrm{N}_{2} \mathrm{O}\right)$ emissions from soil may lead to nonpoint-source pollution in farmland. Improving the $\mathrm{C}$ and $\mathrm{N}$ content in the soil is an excellent strategy to reduce $\mathrm{N}_{2} \mathrm{O}$ emission and mitigate soil $\mathrm{N}$ loss. However, this method lacks a unified mathematical index or standard to evaluate its effect. Methods. To quantify the impact of soil improvement ( $\mathrm{C}$ and $\mathrm{N}$ ) on $\mathrm{N}_{2} \mathrm{O}$ emissions, we conducted a 2-year field experiment using biochar as carbon source and fertilizer as nitrogen source, setting three treatments (fertilization (300 kg N ha ${ }^{-1}$ ), fertilization + biochar (30 $\mathrm{t} \mathrm{ha}^{-1}$ ), control). Results. Results indicate that after biochar application, the average soil water content above $20 \mathrm{~cm}$ increased by $\sim 26 \%$ and $26.92 \%$ in 2019 , and $\sim 10 \%$ and $12.49 \%$ in 2020 . The average soil temperature above $20 \mathrm{~cm}$ also increased by $\sim 2 \%$ and $3.41 \%$ in 2019 . Fertigation significantly promotes the soil N2O emissions, and biochar application indeed inhibited the cumulation by approximately $52.4 \%$ in 2019 and $33.9 \%$ in 2020 , respectively. $\mathrm{N}_{2} \mathrm{O}$ emissions strongly depend on the deep soil moisture and temperature $(20-80 \mathrm{~cm})$, in addition to the surface soil moisture and temperature $(0-20 \mathrm{~cm})$. Therefore, we established an exponential model between the soil moisture and $\mathrm{N}_{2} \mathrm{O}$ emissions based on theoretical analysis. We find that the $\mathrm{N}_{2} \mathrm{O}$ emissions exponentially increase with increasing soil moisture regardless of fertilization or biochar application . Furthermore, the coefficient $a<0$ means that $\mathrm{N}_{2} \mathrm{O}$ emissions initially increase and then decrease. The $\mathrm{a}_{\mathrm{RU}}<\mathrm{a}_{\mathrm{CK}}$ indicates that fertilization does promote the rate of $\mathrm{N}_{2} \mathrm{O}$ emissions. And the $\mathrm{a}_{\mathrm{BRU}}>\mathrm{a}_{\mathrm{RU}}$ indicates that biochar application mitigates this rate induced by fertilization. This conclusion can be verified by the sensitivity coefficient $\left(\mathrm{SC}_{\mathrm{B}}\right.$ of 1.02 and 14.74 ; $\mathrm{SC}_{u}$ of 19.18 and 20.83). Thus, we believe the model can quantify the impact of soil $\mathrm{C}$ and $\mathrm{N}$ changes on $\mathrm{N}_{2} \mathrm{O}$ emissions. We can conclude that biochar does significantly reduce $\mathrm{N}_{2} \mathrm{O}$ 
emissions from farmland. 
1 Effects of fertilizer and biochar applications on the

2 relationship among soil moisture, temperature, and

$3 \mathrm{~N}_{\mathbf{2}} \mathrm{O}$ emissions in farmland

4

5

6

7

8

Xiao Wang ${ }^{1}$, Ping $\mathrm{Lu}^{2}$, Peiling Yang ${ }^{1 *}$ and Shumei Ren ${ }^{1}$

${ }^{1}$ College of Water Resources and Civil Engineering, China Agricultural University, Beijing 100083, China

${ }^{2}$ College of Sericulture, Textile and Biomass Sciences, Southwest University, Chongqing, 400715, China; Corresponding Author:

Peiling Yang ${ }^{1}$

17 East Tsinghua road, Haidian District, Beijing, 100083, China, Email address: cau_yangpeiling@163.com

\section{Abstract}

Background. Di-nitrogen oxide $\left(\mathrm{N}_{2} \mathrm{O}\right)$ emissions from soil may lead to nonpoint-source pollution in farmland. Improving the $\mathrm{C}$ and $\mathrm{N}$ content in the soil is an excellent strategy to reduce $\mathrm{N}_{2} \mathrm{O}$ emissions and mitigate soil $\mathrm{N}$ loss. However, this method lacks a unified mathematical index or standard to evaluate its effect.

Methods. To quantify the impact of soil improvement (C and $\mathrm{N})$ on $\mathrm{N}_{2} \mathrm{O}$ emissions, we conducted a 2-year field experiment using biochar as carbon source and fertilizer as nitrogen source, setting three treatments (fertilization $\left(300 \mathrm{~kg} \mathrm{~N} \mathrm{ha}^{-1}\right)$, fertilization + biochar $\left(30 \mathrm{tha}^{-1}\right)$, control).

Results. Results indicate that after biochar application, the average soil water content above 20 $\mathrm{cm}$ increased by $\sim 26 \%$ and $26.92 \%$ in 2019 , and $\sim 10 \%$ and $12.49 \%$ in 2020 . The average soil temperature above $20 \mathrm{~cm}$ also increased by $2 \%$ and $3.41 \%$ in 2019 . Fertigation significantly promotes the soil $\mathrm{N} 2 \mathrm{O}$ emissions, and biochar application indeed inhibited the cumulation by approximately $52.4 \%$ in 2019 and $33.9 \%$ in 2020 , respectively. $\mathrm{N}_{2} \mathrm{O}$ emissions strongly depend on the deep soil moisture and temperature $(20-80 \mathrm{~cm})$, in addition to the surface soil moisture and temperature $(0-20 \mathrm{~cm})$. Therefore, we established an exponential model between the soil moisture and $\mathrm{N}_{2} \mathrm{O}$ emissions based on theoretical analysis. We find that the $\mathrm{N}_{2} \mathrm{O}$ emissions exponentially increase with increasing soil moisture regardless of fertilization or biochar application. Furthermore, the coefficient a $<0$ means that $\mathrm{N}_{2} \mathrm{O}$ emissions initially increase and then decrease. The $\mathrm{a}_{\mathrm{RU}}<\mathrm{a}_{\mathrm{CK}}$ indicates that fertilization does promote the rate of $\mathrm{N}_{2} \mathrm{O}$ emissions. And the $\mathrm{a}_{\mathrm{BRU}}>\mathrm{a}_{\mathrm{RU}}$ indicates that biochar application mitigates this rate induced by fertilization. This conclusion can be verified by the sensitivity coefficient $\left(\mathrm{SC}_{\mathrm{B}}\right.$ of 1.02 and $14.74 ; \mathrm{SC}_{\mathrm{U}}$ of 19.18 and 20.83). Thus, we believe the model can quantify the impact of soil $\mathrm{C}$ and $\mathrm{N}$ changes 
42

on $\mathrm{N}_{2} \mathrm{O}$ emissions. We can conclude that biochar does significantly reduce $\mathrm{N}_{2} \mathrm{O}$ emissions from farmland.

Keywords: Biochar; $\mathrm{N}_{2} \mathrm{O}$ emissions; Soil moisture; Soil temperature; Fertilization; sensitivity coefficient; multivariate nonlinear fitting; Exponential fitting.

\section{Introduction}

Soil $\mathrm{N}_{2} \mathrm{O}$ emissions, representing a significant $\mathrm{N}$ loss, are inevitable products of chemical fertilizer application (Zou et al. 2005). Based on statistics, greenhouse gas emissions from agricultural sources account for $11 \%$ of the global greenhouse gas emissions, which exceed the 2020 emission target (Zhao et al. 2016). It was considered that the improvement of soil $\mathrm{C}$ and $\mathrm{N}$ content (straw returning, biochar application, etc) is an excellent strategy to reduce $\mathrm{N}_{2} \mathrm{O}$ emission and mitigate soil $\mathrm{N}$ loss. Straw returning significantly mitigated annual $\mathrm{N}_{2} \mathrm{O}$ emission (Yao et al. 2017; Zhou et al. 2017); and compared with the nitrogen fertilizer treatment, the reduction of $\mathrm{N}_{2} \mathrm{O}$ emissions due to straw returning treatment could be as much as $35 \%$ in a particular year (Hu et al. 2016). Biochar application could suppress $\mathrm{N}_{2} \mathrm{O}$ production by $91 \%$ in near-saturated soils (Case et al. 2015). With the considerable amount of biochar application, the $\mathrm{N}_{2} \mathrm{O}$ emissions decreased sharply (Bruun et al. 2011b). Slow-release and controlled-release fertilizer can also help lower $\mathrm{N}_{2} \mathrm{O}$ emissions in farmland (Bordoloi \& Baruah 2016; Braun \& Bremer 2018; Vico et al. 2020). The slow-release fertilizer treatments significantly decreased $\mathrm{N}_{2} \mathrm{O}$ emissions by 16.94 $21.20 \%$ for the rice-wheat cropping system in eastern China (Awais Shakoor et al. 2018). The amendment with a controlled-release fertilizer in soil could help reduce $\mathrm{N}_{2} \mathrm{O}$ emissions by $26-50$ $\%$ than urea application without sacrificing grain yield (Ji et al. 2012). There are many studies on soil improvement using C and N (Ali et al. 2021; Cheng 2020; Liu et al. 2021; Sharmistha et al. 2016), however, they lack a unified mathematical index or standard to evaluate the effect of the research done. The differences of objective conditions in each study make it difficult to draw horizontal comparison of results, which leads to the inability to judge the real effect of soil improvement. A mathematical model or index is required according to the field measured data, to form a unified standard to judge the merits of soil $\mathrm{C}$ and $\mathrm{N}$ improvement, which will be very conducive to the promotion of soil $\mathrm{C}$ and $\mathrm{N}$ improvement in farmland and the sustainable development of agriculture.

Therefore, some more accurate methods, such as mathematical models, are still needed to quantify the impact of soil $\mathrm{C}$ and $\mathrm{N}$ improvement on $\mathrm{N}_{2} \mathrm{O}$ emissions. In addition to increasing soil $\mathrm{C}$ and $\mathrm{N}$, straw returning also increased other nutrient elements ( $\mathrm{Li}$ et al. 2002). We made an improvement in soil $\mathrm{C}$ and $\mathrm{N}$ using biochar and chemical fertilizer application to achieve the controlling variables. Biochar, a form of exogenous carbon, is produced by pyrolysis of straw and branches. The amendment with biochar remarkably affects the physical soil properties (Nanda et al. 2016) and biochemical reactions (Gul et al. 2015; Henrique et al. 2015) and thus affects $\mathrm{C}$ and $\mathrm{N}$ cycles in soil (Liu et al. 2021). 
78

79

80

81

82

83

84

85

86

87

88

89

90

91

92

93

94

95

96

97

98

99

100

101

102

103

104

105

106

107

108

109

110

111

112

113

114

115

116

117

Biochar amendment of soil has many physical effects; for example, it improves the water holding capacity of the soil (Major et al. 2012), nitrate retention (Ghulam et al. 2017; Zhang et al. 2010), and soil aeration (Alfred et al. 2018). The improvement of the soil's water holding capacity due to biochar application is the primary factor inhibiting $\mathrm{N}_{2} \mathrm{O}$ emissions (Basso et al. 2013). Soil moisture affects the production of $\mathrm{N}_{2} \mathrm{O}$ and the conversion of $\mathrm{N}_{2} \mathrm{O}$ to $\mathrm{N}_{2}$. The $\mathrm{N}_{2} \mathrm{O}$ emissions increases and reach a plateau when the water-filled-pore-space (WFPS) is $\sim 60 \%-70 \%$. At the same time, denitrification was maximum. When WFPS was near-saturation, a more anaerobic environment, the $\mathrm{N}_{2} \mathrm{O}$ emissions decrease (Prado et al. 2006). The heat absorption ability of biochar can improve the soil ambient temperature and soil microbial activity. The soil temperature, another critical factor, directly influences the activities of the nitrifying and denitrifying microorganisms and urea hydrolysis (Alvarez et al. 2018). With the increase of soil temperature, microorganisms became more active, biochemical reaction speed increased rapidly, and the efficiency of $\mathrm{N}_{2} \mathrm{O}$ production under the same reaction substrate increased significantly (Case et al. 2012). Compared with the indirect influence of biochar on $\mathrm{N}_{2} \mathrm{O}$ emissions, the fertilizer application added $\mathrm{N}_{2} \mathrm{O}$ reaction substrate, which significantly increased the production efficiency of $\mathrm{N}_{2} \mathrm{O}$. With the substrate increase, the $\mathrm{N}_{2} \mathrm{O}$ sensitivity with soil moisture and temperature increased significantly, changing the $\mathrm{N}_{2} \mathrm{O}$ emission pattern. Many studies set up multiple groups of $\mathrm{C}$ and $\mathrm{N}$ treatments in the laboratory to establish the relationship between soil $\mathrm{C}$ and $\mathrm{N}$ content and $\mathrm{N}_{2} \mathrm{O}$ emission (Feng \& Zhu 2017; Horák et al. 2017; Zwieten et al. 2014).

However, we have made it clear that biochar does not directly affect $\mathrm{N}_{2} \mathrm{O}$ emissions, and it lacks physical significance to establish a function between biochar concentration and $\mathrm{N}_{2} \mathrm{O}$ emissions. Additionally, the $\mathrm{N}_{2} \mathrm{O}$ emission observation made through laboratory tests cannot accurately reflect the actual situation of farmland $\mathrm{N}_{2} \mathrm{O}$ emission. The model just including soil $\mathrm{C}$ content (or $\mathrm{N}$ content) and $\mathrm{N}_{2} \mathrm{O}$ emission is not widely applicable without considering the effect of soil moisture (or soil temperature).

Therefore, to establish an appropriate standard for evaluating the benefits of soil $\mathrm{C}$ and $\mathrm{N}$ improvement, we conducted a 2 -year field experiment using biochar as a carbon source and fertilizer as a nitrogen source. The central hypothesis was that the trend of $\mathrm{N}_{2} \mathrm{O}$ emission under different soil $\mathrm{C}$ and $\mathrm{N}$ levels predicted by measuring soil moisture and temperature could be found out. We hope to 1) explore the response of soil $\mathrm{N}_{2} \mathrm{O}$ emissions to soil moisture and temperature under different conditions (no fertilization, fertilization, fertilization + biochar, and

2) build models and quantify the effects of fertilization and biochar application on $\mathrm{N}_{2} \mathrm{O}$ emissions.

\section{Materials \& Methods}

\section{Experimental site}

The experiments were conducted between 2019-2020 at the experimental station of the China Agricultural University, China (latitude: $39^{\circ} 42^{\prime} 07.8^{\prime \prime} \mathrm{N}$, longitude: $116^{\circ} 41^{\prime} 48.0^{\prime \prime} \mathrm{E}$, altitude: $24 \mathrm{~m}$ ) in loam soil (9.6\% clay, $52.6 \%$ silt, and $37.8 \%$ sand). The mean temperature and precipitation were $26.6{ }^{\circ} \mathrm{C}$ and $358 \mathrm{~mm}$, respectively, in 2019 (April to September); The mean temperature and precipitation were $28.4{ }^{\circ} \mathrm{C}$ and $377 \mathrm{~mm}$, respectively, in 2020 (July to 
118 September). The experimental soil had a soil bulk density of $1.38 \mathrm{~g} \mathrm{~cm}^{-3}$, and the field capacity 119 of the $0-20 \mathrm{~cm}$ soil layer was $22.87 \%$, according to the method from Dane and Jacob (Dane \& 120 Jacob 2002). The soil $(0-20 \mathrm{~cm})$ had an $\mathrm{NH}_{4}^{+}-\mathrm{N}$ of $6.31 \mathrm{mg} \mathrm{kg}^{-1}, \mathrm{NO}_{3}{ }^{-}-\mathrm{N}$ of $29.00 \mathrm{mg} \mathrm{kg}^{-1}$.

121

122

123

124

125

126

127

128

129

130

131

132

133

134

135

136

137

138

139

140

141

142

143

144

145

146

147

148

149

150

151

152

153

154

155

156

\section{Experimental Design}

This experiment aims to establish the relationship between farmland soil moisture, temperature, and $\mathrm{N}_{2} \mathrm{O}$ emissions and explore whether changes in soil $\mathrm{C}$ and $\mathrm{N}$ content can affect $\mathrm{N}_{2} \mathrm{O}$ emissions. Therefore, long-term monitoring of soil moisture, temperature, and $\mathrm{N}_{2} \mathrm{O}$ emissions under different soil $\mathrm{C}$ and $\mathrm{N}$ conditions are required. To make the effect more realistic, we chose maize crop to carry out the research. The maize cultivar Zhengdan 958 is widely used in China. Maize was planted on April 10, 2019, and June 15, 2020, with a $0.5 \mathrm{~m}$ line spacing and $0.3 \mathrm{~m}$ between plants and harvested on September 5 in 2019 and September 25 in 2020. There is a 1-m-wide transition zone between adjacent plots. To creat varying soil $\mathrm{C}$ and $\mathrm{N}$ contents, we set three treatments in the experiment: (1) RU: fertilization with urea, irrigation with reclaimed water; (2) BRU: soil amendment with $30 \mathrm{tha}^{-1}$ biochar, fertilization with urea, and irrigation with reclaimed water; and (3) CK: irrigation with reclaimed water. During the maize growth period, soil moisture and temperature were monitored daily at a depth of $80 \mathrm{~cm}(0-10 \mathrm{~cm}, 10-20$ $\mathrm{cm}, 20-40 \mathrm{~cm}, 40-60 \mathrm{~cm}, 60-80 \mathrm{~cm})$ and $\mathrm{N}_{2} \mathrm{O}$ emission flux in the soil surface was detected every 2-3 days. Then, we explore the correlation between the three variables so as to establish a mathematical model.

The $\mathrm{N}$ fertilizer (urea; $300 \mathrm{~kg} \mathrm{~N} \mathrm{ha}^{-1}$ ) was applied as follows: $40 \%$ before sowing, $30 \%$ during the silking stage, and $30 \%$ during the filling stage. The $\mathrm{P}$ (calcium superphosphate; $40 \mathrm{~kg}$ $\mathrm{P} \mathrm{ha}^{-1}$ ) and $\mathrm{K}$ (potassium sulfate; $80 \mathrm{~kg} \mathrm{~K} \mathrm{ha}^{-1}$ ) fertilizers were applied before sowing. The total irrigation amount for each treatment was $230 \mathrm{~mm}$ in 2019 and $250 \mathrm{~mm}$ in 2020, respectively.

The soil temperature and water content $(0-80 \mathrm{~cm})$ were measured with an ET-100 (Insentek, China). The WFPS was calculated with the following equation:

$W F P S=\left(\frac{\theta_{m} \cdot \rho_{0}}{\rho_{H_{2} O} \cdot \rho_{s}}\right) \cdot 100 \%$,

where $\theta_{\mathrm{m}}$ is the gravimetric water content $\left(\mathrm{mg} \mathrm{mg}^{-1}\right), \rho_{0}$ is the bulk soil density $\left(\mathrm{mg} \mathrm{m}^{-3}\right), \rho_{\mathrm{H} 2 \mathrm{O}}$ is the density of water $\left(\mathrm{mg} \mathrm{m}^{-3}\right)$, and $\rho_{\mathrm{s}}$ is soil particle density $\left(\mathrm{mg} \mathrm{m}^{-3}\right)$.

Biochar was produced by pyrolysis $\left(450{ }^{\circ} \mathrm{C}\right)$ of maize straw and used for the field experiment. The biochar had a $\mathrm{pH}$ of 8.2 , total $\mathrm{C}$ content of $657 \mathrm{~g} \mathrm{~kg}^{-1}$, total $\mathrm{N}$ content of $9 \mathrm{~g} \mathrm{~kg}^{-}$ 1, available $\mathrm{K}$ of $16 \mathrm{~g} \mathrm{~kg}^{-1}$, available $\mathrm{P}$ of $0.8 \mathrm{~g} \mathrm{~kg}^{-1}$, and density of $0.297 \mathrm{~g} \mathrm{~cm}^{-3}$. The biochar was evenly applied to the surface soil $\left(30 \mathrm{t} \mathrm{ha}^{-1}\right.$; top $20 \mathrm{~cm}$ of the soil) in April 2019 before sowing maize. The initial soil had a pH of 9.86, soil organic carbon (SOC) of $29.71 \mathrm{~g} \mathrm{~kg}^{-1}$, soil organic nitrogen (SON) of 2.3, $\mathrm{NH}_{4}{ }^{+}-\mathrm{N}$ of $6.48 \mathrm{mg} \mathrm{kg}^{-1}, \mathrm{NO}_{3}{ }^{-} \mathrm{N}$ of $28.00 \mathrm{mg} \mathrm{kg}^{-1}$, available $\mathrm{K}$ of $38.14 \mathrm{~g}$ $\mathrm{kg}^{-1}$, and available $\mathrm{P}$ of $1.70 \mathrm{~g} \mathrm{~kg}^{-1}$.

\section{Gas collection and analysis}

The $\mathrm{N}_{2} \mathrm{O}$ fluxes were measured at every plot using a static closed chamber method (Qi et al. 2015). The sampling chamber consisted of two parts: a soil ring without top and bottom $(50 \mathrm{~cm}$ in diameter and $30 \mathrm{~cm}$ high) and a removable cover $(50 \mathrm{~cm}$ in diameter and $50 \mathrm{~cm}$ high). The soil

Peer) reviewing PDF | (2020:11:55062:2:0:NEW 29 May 2021) 
157 ring was directly inserted into the soil approximately $25 \mathrm{~cm}$ below the soil surface, leaving $5 \mathrm{~cm}$ 158 from the soil surface. The removable cover was placed on top during the sampling and removed 159 afterward. Two fans with diameters of $10 \mathrm{~cm}$ were installed on the sidewall of each cover to 160 create turbulent airflow when the chamber was closed. Three gas samples were obtained during 161 each treatment and sampling period,i.e., three replicates of one treatment. The soil temperature 162 from 9:00 to 11:00 A.M. was close to the daily mean soil temperature. Thus, we took gas 163 samples during this period. The air temperature inside the static closed chamber was also 164 measured. Gas samples (50 ml each) were collected in four times intervals $(0,10,20$, and 30 $165 \mathrm{~min}$ ) using $50 \mathrm{ml}$ plastic syringes. The $\mathrm{N}_{2} \mathrm{O}$ fluxes were measured after rainfall, fertilization, or 166 every two days. The $\mathrm{N}_{2} \mathrm{O}$ was analyzed using a gas chromatograph (GC 7890 A, Agilent, USA) 167 and electron capture detector (ECD) within $48 \mathrm{~h}$. The $\mathrm{N}_{2} \mathrm{O}$ daily emissions were calculated with 168 the following equation:

169

170

171

172

$F=\rho \times V / A \times(d c / d t) \times 273 /(273+T)$,

where $\mathrm{F}$ is the $\mathrm{N}_{2} \mathrm{O}$ flux $\left(\mathrm{g} \mathrm{m}^{-2} \mathrm{~h}^{-1}\right), \rho$ is the density of the gas in a standardized state $\left(\mathrm{g} \mathrm{m}^{-3}\right), \mathrm{V}$ is the volume of the chamber $\left(\mathrm{m}^{3}\right), \mathrm{A}$ is the cross-sectional area of the chamber $\left(\mathrm{m}^{2}\right), \mathrm{dc} / \mathrm{dt}$ is the rate of gas accumulation $\left(\mu \mathrm{g} \mathrm{kg}^{-1} \mathrm{~h}^{-1}\right)$, and $\mathrm{T}$ is the chamber temperature $\left({ }^{\circ} \mathrm{C}\right)$.

The cumulative $\mathrm{N}_{2} \mathrm{O}$ emissions $\left(\mathrm{kg} \mathrm{ha}^{-1}\right)$ were calculated by using the linear interpolation method.

\section{Chemical analyses}

The $\mathrm{pH}$ values of the biochar and soil were determined with a $\mathrm{pH}$ electrode (Thermo Orion, $420 \mathrm{~A}$ plus). The biochar/deionized water and soil/deionized water ratios were $1: 30 \mathrm{w} / \mathrm{w}$ and 1:10 $\mathrm{w} / \mathrm{w}$, respectively, after being stirred for $1.5 \mathrm{~min}$ and equilibrated for $1 \mathrm{~h}$. The $\mathrm{C}$ and $\mathrm{N}$ concentrations of the biochar and soil were determined using an elemental analyzer (Flash 2000, Thermo Fisher, USA). The available P content was measured with an ultraviolet-visible spectrophotometer (TU-1901 UV-Vis, Beijing Puxi Instrument Company, China). The available $\mathrm{K}$ content was measured with a flame photometer (FAAS; Zenit 700P, Analytik Jena AG, Germany). The $\mathrm{NH}_{4}{ }^{+}-\mathrm{N}$ and $\mathrm{NO}_{3}{ }^{-}-\mathrm{N}$ concentrations were measured using segmented flow analysis (SFA; Futura, Alliance, France).

\section{Model}

$\mathrm{N}_{2} \mathrm{O}$ emissions are the result of soil biochemical reactions, which are slow. $\mathrm{N}_{2} \mathrm{O}$ emission at a particular time may arise from the cumulative effects of water and temperature in the previous period. Therefore, the lag effects should be considered. We assume that the $\mathrm{N}_{2} \mathrm{O}$ emission during sampling is caused by the influence of soil moisture and temperature in the previous $24 \mathrm{~h}$. If sampling occurs at 9:00 am on July 23 , the $\mathrm{N}_{2} \mathrm{O}$ flux is affected by the soil moisture (or temperature) between 10:00 A.M. on July 22, and 9:00 A.M. on July 23. ET-100 can monitor a series of soil moistures and temperatures hourly. Therefore, we established a function between 
$197 \mathrm{~N}_{2} \mathrm{O}$ flux and the average soil moisture (or temperature) in the past $24 \mathrm{~h}$. This function was

198

199

200

201

202

203

204

205

206

207

208

209

210

211

212

213

214

215

216

217

218

219

220

221

222

223

224

225

226

227

228

229

230

231

232

233

234

235

created to calculate the daily soil moisture and temperature at 9:00 as the node.

A) Relationship among the soil temperature, water content, and $\mathrm{N}_{2} \mathrm{O}$ emissions

The principal component analysis is a statistical method. It transformed a group of correlated variables into a group of linearly unrelated variables based on orthogonal transformation. The transformed variables are called principal components (Stacklies et al. 2007). Through principal component analysis, we have synthesized numerous indexes and eliminated the sample's overlapping (Granato et al. 2018; He et al. 2018; Imaizumi \& Kato 2018). The expression of the principal component was as follows:

$$
\begin{gathered}
W 1=a \cdot W_{10}^{*}+b \cdot W_{20}^{*}+c \cdot W_{40}^{*} \\
T 1=d \cdot T_{10}^{*}+e \cdot T_{20}^{*}+f \cdot T_{40}^{*},
\end{gathered}
$$

where $\mathrm{W} 1$ or $\mathrm{T} 1$ is the principal components obtained by extracting the soil water content or temperature from the 10,20 , and $40 \mathrm{~cm}$ soil layers, respectively; $\mathrm{W}_{10}{ }^{*}, \mathrm{~W}_{20}{ }^{*}, \mathrm{~W}_{40}{ }^{*}, \mathrm{~T}_{10}{ }^{*}, \mathrm{~T}_{20}{ }^{*}$, and $\mathrm{T}_{40}{ }^{*}$ are the standardized soil water contents and temperatures corresponding to the 10, 20. and $40 \mathrm{~cm}$ soil layers, respectively; and a, b, c, d, e, and fare the standardized coefficients of the values, respectively.

Because the principal component 1 (PC1) accounts for more than $70 \%$ of the variation, only $\mathrm{PC} 1$ of the soil moisture content (or temperature) was used for multivariate nonlinear fitting. Table 1 shows that the PC1 covers the soil moisture content and temperature information of the 10,20 , and $40 \mathrm{~cm}$ soil layers. The moisture content and temperature of the $20 \mathrm{~cm}$ soil layer contribute the most to the PC1.

The parameter $\mathrm{F}^{*}{ }_{\mathrm{N}}$ was obtained by standardizing the daily $\mathrm{N}_{2} \mathrm{O}$ emissions and fitting with $\mathrm{W} 1$ and $\mathrm{T} 1$ :

$$
F_{N}^{*}(W 1, T 1)=z_{0}+k 1 * W 1+k 2 * T 1+k 3 * W 1^{2}+k 4 * T 1^{2}+k 5 * W 1 \cdot T 1,
$$

Where $\mathrm{k} 1(\mathrm{k} 2, \mathrm{k} 3, \mathrm{k} 4, \mathrm{k} 5)$ is the coefficient and $\mathrm{z}_{0}$ is the constant.

Table 2 shows the value of the coefficient in Eq. (5).

Equations (3) and (4) were substituted into Eq. (5) to obtain:

$$
F^{*}\left(W_{10}^{*}, W_{20}^{*}, W_{40}^{*}, T_{10}^{*}, T_{20}^{*}, T_{40}^{*}\right)=z_{0}+k_{1} \cdot a \cdot W_{10}^{*}+k_{1} \cdot b \cdot W_{20}^{*}+k_{1} \cdot c \cdot W_{40}^{*}+k_{2} \cdot d \cdot T_{10}^{*}
$$

$+k_{2} \cdot e \cdot T_{20}^{*}+k_{2} \cdot f \cdot T_{40}^{*}+k_{3} \cdot\left(a \cdot W_{10}^{*}+b \cdot W_{20}^{*}+c \cdot W_{40}^{*}\right)^{2}+k_{4} \cdot$

$\left(d \cdot T_{10}^{*}+e \cdot T_{20}^{*}+f \cdot T_{40}^{*}\right)^{2}+k_{5} \cdot\left(a \cdot W_{10}^{*}+b \cdot W_{20}^{*}+c \cdot W_{40}^{*}\right) \cdot\left(d \cdot T_{10}^{*}+e \cdot T_{20}^{*}+f \cdot T_{40}^{*}\right)$

(6) 
244

245

246

247

248

249

250

251

252

253

254

255

256

257

258

259

260

261

262

263

264

265

266

267

268

269

270

271

272

273

274

B) Response of the $\mathrm{N}_{2} \mathrm{O}$ emissions to WFPS

We assumed that the $\mathrm{N}_{2} \mathrm{O}$ emissions exponentially increase with increasing WFPS and that the emission rate of $\mathrm{N}_{2} \mathrm{O}$ initially increases and then decreases. Thus, $d D E / d W$ initially is positive and then negative. The model of the $\mathrm{N}_{2} \mathrm{O}$ emissions can be obtained as follows:

$$
\frac{1}{D E} \frac{d D E}{d W}=B-A W
$$

Where DE represents the daily emissions of $\mathrm{N}_{2} \mathrm{O}\left(\mathrm{kg} \mathrm{hm}^{-2}\right)$, W is the WFPS, and A and B are constants.

To illuminate the mitigation of the $\mathrm{N}_{2} \mathrm{O}$ emissions due to biochar amendment, we adopted the sensitivity coefficient (SC) to express the effect of the change in the soil water content on the $\mathrm{N}_{2} \mathrm{O}$ emissions (Tan et al. 2017). The smaller $\mathrm{SC}$ is, the smaller is the response of the $\mathrm{N}_{2} \mathrm{O}$ emissions to the change in the soil water content. The SC can be calculated as:

$$
S C=\frac{\sum\left(\Delta D E / D E_{0}\right)}{\sum\left(\Delta W / W_{0}\right)}
$$

Where $\triangle \mathrm{DE}$ is the variation in the $\mathrm{N}_{2} \mathrm{O}$ emissions between the BRU/RU and CK treatments, $\Delta \mathrm{W}$ is the variation in the WFPS between the BRU/RU and CK treatments, and $\mathrm{DE}_{0}$ and $\mathrm{W}_{0}$ represent the $\mathrm{N}_{2} \mathrm{O}$ emissions and WFPS of treatment CK, respectively.

Equation (9), obtained by integrating Eq. (7), is a numerical model describing the increase in the $\mathrm{N}_{2} \mathrm{O}$ emissions for different WFPS values under irrigation.

$$
D E=e^{a W^{2}+b W+c},
$$

Where $\mathrm{a}$ is $\mathrm{A} / 2, \mathrm{~b}$ is $\mathrm{B}$, and $\mathrm{c}$ is an integral constant.

\section{Statistical analysis}

The data were analyzed with SPSS20.0 software. Variance analysis (ANOVA) was carried out by using the General Linear Model Univariate procedure. The analysis of significant differences $(p<0.05)$ between treatments was carried out using Tukey's range test. We also prepared figures and fitted the models using OriginPro 2019.

\section{Results}

\section{Soil water content and temperature}

The experimental area was irrigated with $60 \mathrm{~mm}$ reclaimed water after sowing. The next irrigation step was conducted at the seeding stage. We observed a drastic fluctuation in the soil water content above a depth of $20 \mathrm{~cm}$ during each treatment. Such a fluctuation did not occur in the $60-\mathrm{cm}$ and $80-\mathrm{cm}$ soil layers (Fig. 1). In 2019, the average soil water content above $20 \mathrm{~cm}$ in the BRU treatment was $\sim 26 \%$ and $26.92 \%$ higher than that of the RU and CK treatments, 
275 respectively. And The average soil water content $(0-20 \mathrm{~cm})$ in BRU also showed this trend in

276 2020: it was $\sim 10 \%$ and $12.49 \%$ higher than those in RU and CK treatments, respectively.

277 However, the difference in soil water content between these treatments was not pronounced

278 below a depth of $40 \mathrm{~cm}$. Many researchers have reported that biochar, owing to the great voids 279 on the surface, can improve soil moisture content (Arezoo et al. 2011; Qu et al. 2020; Zhang et 280 al. 2019b). Thus, we can conclude that the soil amendment with biochar significantly promotes 281 the water holding capacity.

282

283

284

285

286

287

288

289

290

291

292

293

294

295

296

297

298

299

300

301

302

303

304

305

306

307

308

309

310

311

312

313

Figure 1: The soil water content for each treatment in the depth of $10 \mathrm{~cm}, 20 \mathrm{~cm}, 40 \mathrm{~cm}, 60$ $\mathrm{cm}$, and $80 \mathrm{~cm}$ during 2019-2020 is presented; (A), (B), and (C) show the soil water content in RU, BRU, and CK treatments in 2019, respectively; (D), (E), and (F) show the soil water content in RU, BRU, and CK treatments in 2020 respectively.

The variation in soil temperature in the maize growth stage for each treatment is shown in Fig. 2. Obviously, the temperature of the surface soil fluctuates more dramatically than that of the deep soil. The accumulative temperature difference between BRU and RU at a depth of 40 $\mathrm{cm}$ were $-4^{\circ} \mathrm{C}$ and $-11^{\circ} \mathrm{C}$ in 2019 and 2020, respectively (Fig. 2). The average soil temperature for BRU treatment was obviously lower than that for RU treatment below $40 \mathrm{~cm}$ in 2020 (Fig. 2). These results imply that biochar inhibits temperature transfer from the surface to deep soil. In 2019, the average soil temperature above $20 \mathrm{~cm}$ of the BRU treatment was $\sim 2 \%$ and $3.41 \%$ higher than that of the RU and CK treatments, respectively. However, in 2020, the BRU treatment showed no warming effect and reduced water holding capacith. It may be caused by biochar aging (Zhang et al. 2013).

Figure 2: The soil temperature for each treatment in the depth of $10 \mathrm{~cm}, 20 \mathrm{~cm}, 40 \mathrm{~cm}, 60 \mathrm{~cm}$, and $80 \mathrm{~cm}$ during 2019-2020 is presented; (A), (B), and (C) show the soil temperature for RU, BRU, and CK treatment in 2019, respectively; (D), (E), and (F) show the soil temperature for RU, BRU, and CK treatment in 2020.

\section{Soil $\mathrm{N}_{2} \mathrm{O}$ emissions}

Chemical fertilizer application significantly promotes the soil $\mathrm{N}_{2} \mathrm{O}$ emissions (Fig. 3). The significant difference in $\mathrm{N}_{2} \mathrm{O}$ emissions between these treatments occurred between June 13 and July 3 in 2019 and on July 29 and August 28 in 2020. The emission flux of $\mathrm{N}_{2} \mathrm{O}$ was significantly higher for RU than for BRU and $\mathrm{CK}$ at this time. The cumulative $\mathrm{N}_{2} \mathrm{O}$ emissions for the RU treatment are $3.61 \mathrm{~kg} \mathrm{ha}^{-1}$ compared with 1.72 and $1.59 \mathrm{~kg} \mathrm{ha}^{-1}$ for the BRU and CK treatments, respectively, in 2019. The increment of $\mathrm{N}_{2} \mathrm{O}$ emissions for RU treatment was $4.54 \mathrm{~kg}$ $\mathrm{ha}^{-1}$ compared with 3.00 and $0.78 \mathrm{~kg} \mathrm{ha}^{-1}$ for the BRU and CK treatments, respectively, in 2020. Thus, we could find that fertilization significantly enhanced $\mathrm{N}_{2} \mathrm{O}$ emissions for the two years and biochar application alleviated this trend. Our results are consistent with those of many previous 
314 studies, showing that biochar can indeed inhibit $\mathrm{N}_{2} \mathrm{O}$ emissions from farmland (Bruun et al.

315 2011a; Cayuela et al. 2014; Takakai et al. 2019).

316

317

318

319

320

321

322

323

324

325

326

327

328

329

330

331

332

333

334

335

336

337

338

339

340

341

342

343

344

345

346

347

348

349

350

351

352

353

Figure 3: $\mathrm{N}_{2} \mathrm{O}$ emissions in the maize growth stage is presented. (A) and (B) show the $\mathrm{N}_{2} \mathrm{O}$ emissions in 2019 and 2020, respectively.

\section{The correlation among the soil water content, temperature, and $\mathrm{N}_{2} \mathrm{O}$ emissions}

The soil $\mathrm{N}_{2} \mathrm{O}$ emissions were strongly correlated with the soil water content at a depth above $40 \mathrm{~cm}$ in all the treatments (Table 1). The correlation between the soil $\mathrm{N}_{2} \mathrm{O}$ emissions and soil temperature was also pronounced at depth above $40 \mathrm{~cm}$ for RU and BRU. Both soil water content and temperature affect the soil $\mathrm{N}_{2} \mathrm{O}$ emissions. Thus, it is imperative to analyze the coupled effect of the soil water content and temperature on the $\mathrm{N}_{2} \mathrm{O}$ emissions.

Table 1: Correlation among soil water content, temperature, and $\mathrm{N}_{2} \mathrm{O}$ emissions.

\section{Establishing function among soil water content, temperature, and $\mathrm{N}_{2} \mathrm{O}$ emissions}

Table 1 shows that soil water content and temperature at a depth above $80 \mathrm{~cm}$ affect the $\mathrm{N}_{2} \mathrm{O}$ emissions. Soil water content, temperature and $\mathrm{N}_{2} \mathrm{O}$ emissions are strongly correlated at depths of $0-40 \mathrm{~cm}$, while the correlation is weak in the $60-80 \mathrm{~cm}$ soil layer. Therefore, we set up a function model for soil water content, temperature and $\mathrm{N}_{2} \mathrm{O}$ emissions above $40 \mathrm{~cm}$. To simplify the calculation, we performed principal components analysis on moisture content and temperature in the 10,20, and $40 \mathrm{~cm}$ soil layers. Table 2 and Table 3 show the value of coefficient in Eq. (3)-(5), respectively.

Table 2: Coefficient of PC1.

Table 3: Coefficient of multiple nonlinear regression.

Compared with a single soil layer (10-, 20-, or 40-cm), the soil $\mathrm{N}_{2} \mathrm{O}$ emissions can be predicted more accurately by combining the moisture contents and temperatures of the three soil layers [Eq. (6)]. The water contents and temperatures of the three soil layers affect the $\mathrm{N}_{2} \mathrm{O}$ emissions to different degrees. Therefore, we believe that the soil $\mathrm{N}_{2} \mathrm{O}$ emissions are due to the combined effect of the moisture content and temperature of the 0-40-cm soil layer. Moreover, the three treatments cannot be adequately fit with one regression equation $\left(\mathrm{R}^{2}, 0.51\right.$ in 2019). When multivariate nonlinear fitting was applied to the three treatments, an $\mathrm{R}^{2}$ value above 0.60 was obtained (Fig. 4). The results show that the $\mathrm{N}_{2} \mathrm{O}$ emissions in the RU treatment are significantly higher than those in the BRU and CK treatments (Fig. 3), indicating that the soil environment (two or more variables) significantly affects the response of the soil $\mathrm{N}_{2} \mathrm{O}$ emissions to changes the moisture content and temperature. When the soil environment was changed by fertilization and biochar amendment, the accuracy of multivariate nonlinear fitting decreased significantly, as per dimensionality reduction analysis (MNF-DR). This is due to the changes in 
354

355

356

357

358

359

360

361

362

363

364

365

366

367

368

369

370

371

372

373

374

375

376

377

378

379

380

381

382

383

384

385

386

387

388

389

390

391

392

393

soil biochemical reaction rate due to fertilization or biochar amendment (Bruun et al. 2014; Saarnio et al. 2013) and changes in the response of the $\mathrm{N}_{2} \mathrm{O}$ emissions to moisture content and temperature.

Figure 4: The fitting about WFPS, soil temperature, and $\mathrm{N}_{2} \mathrm{O}$ emissions based on MNF-DR analysis for each treatment during 2019-2020 is presented; (A) and (E) represents the measured data of the three treatments (RU + BRU + CK) we used for MNF-DR analysis in 2019 and 2020, respectively; (B) and (F) represents the measured data of RU we used for MNF-DR analysis in

2019 and 2020, respectively; (C) and (G) represents the measured data of BRU we used for MNF-DR analysis in 2019 and 2020, respectively; (D) and (H) represents the measured data of CK we used for MNF-DR analysis in 2019 and 2020, respectively.

Researchers have also suggested that the soil water content (or temperature) at a depth of 5 $\mathrm{cm}$ can be identified as the single trigger for $\mathrm{N}_{2} \mathrm{O}$ emission (Lognoul et al. 2019). We acknowledge that most $\mathrm{N}_{2} \mathrm{O}$ emissions originate from biochemical reactions in the topsoil, but some $\mathrm{N}_{2} \mathrm{O}$ emissions still arise from deep soil via nitrification and denitrification. The $\mathrm{N}_{2} \mathrm{O}$ produced in the deep soil will diffuse to the surface at a rate that depends on the soil moisture content and the $\mathrm{N}_{2} \mathrm{O}$ concentration gradient (Shcherbak \& Robertson 2019). Furthermore, storage fluxes occurred in the deep soil. Lognoul et al. (2019) assumed that storage fluxes were negligible. However, the soil moisture content and temperature in the $0-40 \mathrm{~cm}$ soil layer were significantly correlated with $\mathrm{N}_{2} \mathrm{O}$ emissions; therefore, physical factors from topsoil cannot be accurately identified as the single trigger for $\mathrm{N}_{2} \mathrm{O}$ emissions.

The predictions using MNF-DR are more stable than those based on the surface soil moisture content and temperature only. However, with MNF-DR analysis, only the $\mathrm{N}_{2} \mathrm{O}$ emissions at the farmland scale can be predicted from the perspective of statistics. The $\mathrm{N}_{2} \mathrm{O}$ emissions trends depending on changes microscale in the water content or temperature cannot be explained. Moreover, the relationship $\mathrm{k} 4_{\mathrm{BRU}}>\mathrm{k} 4_{\mathrm{RU}}$ indicates that the $\mathrm{N}_{2} \mathrm{O}$ emission rate of $\mathrm{BRU}$ was greater than that of $\mathrm{RU}$ (Table 3). In fact, the $\mathrm{N}_{2} \mathrm{O}$ emissions rate of biochar treatment should be even lower. Thus, it is difficult to predict the $\mathrm{N}_{2} \mathrm{O}$ emissions trend of each treatments from this MNF-DR analysis. We need a more accurate model to predict the impact of biochar on the $\mathrm{N} 2 \mathrm{O}$ emissions rate.

\section{Establishing function among soil water content, and $\mathrm{N}_{2} \mathrm{O}$ emissions}

The emission rate of $\mathrm{N}_{2} \mathrm{O}$ increases with increasing soil moisture content based on this field experiment, while the increase in the $\mathrm{N}_{2} \mathrm{O}$ emissions slows down after the WFPS exceeds $80 \%$. Previous studies showed that the $\mathrm{N}_{2} \mathrm{O}$ emissions increase until the WFPS reaches $\sim 75 \%$ (Lan et al. 2013). However, the $\mathrm{N}_{2} \mathrm{O}$ emissions rate decreases when the soil water content exceeds a WFPS of 75\% (Prado et al. 2006) because the anaerobic environment accelerates the reduction of $\mathrm{N}_{2} \mathrm{O}$ to $\mathrm{N}_{2}$ in the soil (Wu et al. 2013). The soil represents a $\mathrm{N}_{2} \mathrm{O}$ sink when the WFPS is below 25\% (Flechard et al. 2007; Goldberg \& Gebauer 2008; Wu et al. 2013). 
394

395

396

397

398

399

400

401

402

403

404

405

406

407

408

409

410

411

412

413

414

415

416

417

418

419

420

421

422

423

424

425

426

427

428

429

430

431

432

433

Thus, we assume that the rate of $\mathrm{N}_{2} \mathrm{O}$ emissions varies with the WFPS. The rate of $\mathrm{N}_{2} \mathrm{O}$ emissions was low at a low WFPS. and increased sharply with increasing WFPS. When the WFPS exceeds a particular value, the increase in the soil $\mathrm{N}_{2} \mathrm{O}$ emissions slowed down despite the continuous increase in the WFPS. The WFPS ranges from 0 to 1 ; the emitted $\mathrm{N}_{2} \mathrm{O}$ responds to a variation in the WFPS.

The soil was amended with biochar at a depth above $20 \mathrm{~cm}$ and we fitted the model for the 20 -cm soil layer to reduce the influence of soil water evaporation. For each treatment, the $\mathrm{N}_{2} \mathrm{O}$ emissions were plotted against the WFPS (Fig. 5). These values were fitted using Eq. (9), yielding a strong positive correlation (Table 4). Thus, Eq. (8) explains the $\mathrm{N}_{2} \mathrm{O}$ emissions well. The smaller the coefficient a is, the smaller the growth rate of $\mathrm{N} 2 \mathrm{O}$ emission is (Eq. (9)). The relationship $\mathrm{a}_{\mathrm{BRU}}>\mathrm{a}_{\mathrm{RU}}$ indicates that the $\mathrm{N}_{2} \mathrm{O}$ emissions rate of BRU is lower than that of $\mathrm{RU}$ (Table 4). Thus, after biochar application, $\mathrm{N}_{2} \mathrm{O}$ emissions increased significantly with increasing WFPS after fertilization (Fig. 6). To quantify the effect of biochar on the $\mathrm{N}_{2} \mathrm{O}$ emissions, the SC [Eq. (9)] was determined, which has been applied in many previous studies (Engel et al. 2017; Joby \& Mahanthesh 2019; Tan et al. 2017). The SC of RU versus CK ( $\left.\mathrm{SC}_{\mathrm{U}}\right)$ is 19.18 and 20.83 in 2019, respectively. and The SC of BRU versus $\mathrm{CK}\left(\mathrm{SC}_{\mathrm{B}}\right)$ is 1.02 in 2019 and 14.74 in 2020, respectively. Thus, we can conclude that biochar significantly reduces the $\mathrm{N}_{2} \mathrm{O}$ emissions, which efficiently inhibits the $\mathrm{N}$ loss.

Figure 5: The fitting about WFPS and $\mathrm{N}_{2} \mathrm{O}$ emissions based on the exponential model for each treatment during 2019-2020 is presented; (A) and (D) represents the measured data of RU we used for the exponential model in 2019 and 2020, respectively; (B) and (E) represents the measured data of BRU we used for the exponential model in 2019 and 2020, respectively; (C) and (F) represents the measured data of CK we used for the exponential model in 2019 and 2020, respectively.

Table 4: Coefficients, determinative factor, and F value of Eq. (9).

\section{Discussion}

$\mathrm{N}_{2} \mathrm{O}$ is an intermediate product that is formed during both denitrification and nitrification (Dobbie \& Smith 2001). Soil moisture is the most critical factor governing $\mathrm{N}_{2} \mathrm{O}$ and $\mathrm{NO}$ formation when mineral $\mathrm{N}$ sources in soil are limited (Prado et al. 2006). $\mathrm{N}_{2} \mathrm{O}$ emissions have been reported to increase until the WFPS reaches $\sim 72 \%$ (Schmidt et al. 2000), while other have been some reported of a threshold reaching up to $90 \%$ (Dobbie \& Smith 2001). The positive correlation coefficient between the $\mathrm{N}_{2} \mathrm{O}$ emissions and WFPS obtained in our study implies that an increase in the soil water content promotes the soil $\mathrm{N}_{2} \mathrm{O}$ emissions (Table 1). The soil water content indirectly affects the soil $\mathrm{N}_{2} \mathrm{O}$ emissions because the volumetric gas content affected by the WFPS is a vital factor governing both nitrification and denitrification (Clough et al. 2017). Denitrification mainly occurs above a WFPS of 60-70\%, whereas nitrification occurs at a WFPS of $35 \%$ and $60 \%$ (Bateman \& Baggs 2005). Most $\mathrm{N}_{2} \mathrm{O}$ originates from nitrification when the 
434 WFPS is below $60 \%$, while an increased conversion from $\mathrm{N}_{2} \mathrm{O}$ to $\mathrm{N}_{2}$ occurred at higher soil

435

436

437

438

439

440

441

442

443

444

445

446

447

448

449

450

451

452

453

454

455

456

457

458

459

460

461

462

463

464

465

466

467

468

469

470

471

472

473

water contents (Wu et al. 2013). Thus, the emission flux of the soil $\mathrm{N}_{2} \mathrm{O}$ decreases when denitrification was dominant, although the cumulative $\mathrm{N}_{2} \mathrm{O}$ emissions continue to increase (Figs 5-6). This conclusion agrees with the results of other studies, in which a nonlinear $\mathrm{N}_{2} \mathrm{O}$ emission response to $\mathrm{N}$ fertilizer addition was reported (Clairep 2005; Prado et al. 2006).

Figure 6: Determinants of soil $\mathrm{N}_{2} \mathrm{O}$ emissions.

The soil $\mathrm{N}$ availability may have a significant impact on the $\mathrm{N}_{2} \mathrm{O}$ emissions. $\mathrm{N}$ fertilization, a direct measure of the increase in the soil $\mathrm{N}$ availability, promotes the $\mathrm{N}_{2} \mathrm{O}$ emissions compared with the unfertilized control (Lei et al. 2005).

Biochar application led to a significant increase in the soil water content in the topsoil (0-20 $\mathrm{cm}$ ) relative to the unamended biochar treatments (Fig. 1). Many studies have been carried out to improve the soil water holding capacity, which should enhance the water use efficiency in agricultural production (Basso et al. 2013; Oki 2006). Amendment with biochar significantly mitigates the soil $\mathrm{N}_{2} \mathrm{O}$ emissions, particularly at a WFPS above $60 \%$ (Fig. 6). Previous studies have shown that the $\mathrm{N}_{2} \mathrm{O}$ emissions from biochar-amended soil were sharply reduce because the biochar adsorbed inorganic $\mathrm{N}$ and thus decreased the $\mathrm{N}$ concentration available for nitrification and denitrification (Arezoo et al. 2011; Cayuela et al. 2014; Stewart et al. 2013). Moreover, the response of the decreased $\mathrm{N}_{2} \mathrm{O}$ emissions to temporary immobilization of available $\mathrm{N}$ was derived from a high C:N ratio after biochar amendment (Baggs et al. 2000). The decreased $\mathrm{N}$ availability due to biochar adsorption only partly explains the reduction of the $\mathrm{N}_{2} \mathrm{O}$ emissions compared with the BRU and RU treatments. Because of the strong correlation between the WFPS and soil $\mathrm{N}_{2} \mathrm{O}$ emissions, the amendment with biochar also mitigates the $\mathrm{N}_{2} \mathrm{O}$ emissions by increasing the soil water content (Table 1). This result is consistent with the finding that the anaerobic environment caused by a high soil water content increases the abundance of denitrifying bacteria and thus catalytically reduces $\mathrm{N}_{2} \mathrm{O}$ to $\mathrm{N}_{2}$ (Wu et al. 2013). Other studies have shown that biochar significantly increases the soil $\mathrm{N}_{2} \mathrm{O}$ emissions under increased $\mathrm{N}$ availability due to fertilization (Clough et al. 2010; Rajkovich et al. 2012). It is possible that incomplete nitrification occurs after amendment with biochar (Clough et al. 2017). Biochar increase surface soil temperatures, which in turn increases $\mathrm{N}_{2} \mathrm{O}$ emissions. The effect of temperature on $\mathrm{N}_{2} \mathrm{O}$ emission was due to the promotion of the microbial activity. High temperatures could also enhance the denitrifying bacteria activity, promoting the conversion of $\mathrm{N}_{2} \mathrm{O}$ to $\mathrm{N}_{2}$. Nevertheless, biochar only increases the surface soil temperature $(0-10 \mathrm{~cm})$. The model shows that $\mathrm{N}_{2} \mathrm{O}$ emission was affected by soil moisture (or temperature) above a depth of $40 \mathrm{~cm}$ depth. Therefore, a small temperature increase does not have a significant impact on $\mathrm{N}_{2} \mathrm{O}$ emissions.

Biochar enhances soil nitrogen and water immobilization, promotes crop photosynthesis, and increased crop yield (Macdonald et al. 2014; Zhao et al. 2014). Compared with straw returns, biochar can improve soil physical and chemical properties of soil, enhance the

Peer) reviewing PDF | (2020:11:55062:2:0:NEW 29 May 2021) 
474

475

476

477

478

479

480

481

482

483

484

485

486

487

488

489

490

491

492

493

494

495

496

497

498

499

500

501

502

503

504

505

506

507

508

509

510

511

512

513

514

515

516

effectiveness of water and fertilizers, and reduce chemical fertilizer pollution. However, expensive straw carbonization equipment restricts the market development of biochar and its implication, and the production rate of carbonization equipment does not reach the standard of large-scale production (Zhang et al. 2019a). Therefore, low-cost and large-scale biochar production biochar is a challenge in developing agricultural ecology.

\section{Conclusions}

In this research, we have established an appropriate standard for evaluating soil $\mathrm{C}$ and $\mathrm{N}$ improvement benefits. MNF-DR analysis was difficult to predict the $\mathrm{N}_{2} \mathrm{O}$ emissions trend, especially when WFPS was above $70 \%\left(\mathrm{k} 4_{\mathrm{BRU}}>\mathrm{k} 4_{\mathrm{RU}}\right)$. The exponential model can accurately simulate the $\mathrm{N}_{2} \mathrm{O}$ emission trend based on WFPS $\left(\mathrm{R}^{2}>0.59\right)$. That is, the emission rate of $\mathrm{N}_{2} \mathrm{O}$ initially increased and then decreased with the increased WFPS, which was consistent with the previous study. The relationship $\mathrm{a}_{\mathrm{RU}}<\mathrm{a}_{\mathrm{CK}}$ indicates that fertilization did promote $\mathrm{N}_{2} \mathrm{O}$ emissions, while $\mathrm{a}_{\mathrm{BRU}}>\mathrm{a}_{\mathrm{RU}}$ indicated that biochar applications mitigate the $\mathrm{N}_{2} \mathrm{O}$ emissions induced by fertilization (Table 4). Moreover, The SC of RU versus CK ( $\left.\mathrm{SC}_{\mathrm{U}}\right)$ was 19.18 and 20.83 in 2019 and 2020, respectively, while the SC of BRU versus $\mathrm{CK}\left(\mathrm{SC}_{\mathrm{B}}\right)$ is 1.02 in 2019 and 14.74 in 2020 , respectively, indicating that biochar significantly reduced the sensitivity of $\mathrm{N}_{2} \mathrm{O}$ to the substrate, which reduces the $\mathrm{N}_{2} \mathrm{O}$ emissions.

From the exponential model, we believe that the input of biochar and urea did not change the $\mathrm{N}_{2} \mathrm{O}$ emissions trend in dryland farming. Furthermore, the exponential model confirmed that biochar indeed reduced the $\mathrm{N}_{2} \mathrm{O}$ emissions flux induced by urea application. However, our study was based on the physical properties of biochar (water-holding capacity) to explore the greenhouse gas emissions pattern. When the added carbon source is organic matter, such as organic fertilizer and straw, the accuracy of this model needs to be further revised. In a word, we suggested that the exponential model can be used to quantify the impact of biochar and urea on soil $\mathrm{N}_{2} \mathrm{O}$ emissions in dryland farming.

\section{References}

Alfred O, Mulder J, Hale SE, Nurida NL, Cornelissen G, and Paz-Ferreiro J. 2018. The potential of biochar in improving drainage, aeration and maize yields in heavy clay soils. Plos One 13:e0196794-.

Ali EF, Al-Yasi HM, Kheir A, and Eissa MA. 2021. Effect of Biochar on CO 2 Sequestration and Productivity of Pearl Millet Plants Grown in Saline Sodic Soils. Journal of Soil Science and Plant Nutrition.

Alvarez G, Shahzad T, Andanson L, Bahn M, and Fontaine S. 2018. Catalytic power of enzymes decreases with temperature: New insights for understanding soil $\mathrm{C}$ cycling and microbial ecology under warming. Global Change Biology 24.

Arezoo T, Toosi., Clough TJ, Condron LM, Sherlock RR, Anderson CR, and Craigie RA. 2011. Biochar Incorporation into Pasture Soil Suppresses in situ Nitrous Oxide Emissions from Ruminant Urine Patches. Journal of Environmental Quality 40.

Awais Shakoor, Yunlian Xu, Qiang Wang, Ningyi Chen, Fei He, Huaifeng Zuo, Hanxun Yin, Xiaoyuan Yan, Youhua Ma, and Yang S. 2018. Effects of fertilizer application schemes

Peer] reviewing PDF | (2020:11:55062:2:0:NEW 29 May 2021) 
517

518

519

520

521

522

523

524

525

526

527

528

529

530

531

532

533

534

535

536

537

538

539

540

541

542

543

544

545

546

547

548

549

550

551

552

553

554

555

556

557

558

559

560

561

562

563

564

565

566 and soil environmental factors on nitrous oxide emission fluxes in a rice-wheat cropping system, east China. Plos One 13:e0202016.

Baggs EM, Watson CA, and Rees RM. 2000. The fate of nitrogen from incorporated cover crop and green manure residues. Nutrient Cycling in Agroecosystems 56:153-163.

Basso AS, Miguez FE, Laird DA, Horton R, and Westgate M. 2013. Assessing potential of biochar for increasing water-holding capacity of sandy soils. Global Change Biology Bioenergy 5:132-143.

Bateman EJ, and Baggs EM. 2005. Contributions of nitrification and denitrification to N 20 emissions from soils at different water-filled pore space. Biology and Fertility of Soils 41.

Bordoloi N, and Baruah KK. 2016. A two-year field assessment on the effect of slow release of nitrogenous fertiliser on N2O emissions from a wheat cropping system. Soil Research 55.

Braun RC, and Bremer DJ. 2018. Nitrous Oxide Emissions in Turfgrass Systems: A Review. Agronomy journal 110.

Bruun EW, Müller-St?ver D, Ambus P, and Hauggaard-Nielsen H. 2011a. Application of biochar to soil and N2O emissions: potential effects of blending fast-pyrolysis biochar with anaerobically digested slurry. European Journal of Soil Science 62:581-589.

Bruun EW, Müller-St?Ver D, Ambus P, and Hauggaard-Nielsen H. 2011b. Application of biochar to soil and $\mathrm{N} 2 \mathrm{O}$ emissions: potential effects of blending fast - pyrolysis biochar with anaerobically digested slurry. European Journal of Soil Science 62:581-589.

Bruun EW, Petersen CT, Hansen E, Holm JK, and Hauggaard - Nielsen H. 2014. Biochar amendment to coarse sandy subsoil improves root growth and increases water retention. Soil Use \& Management 30:109-118.

Case S, Mcnamara NP, Reay DS, Stott AW, Grant HK, and Whitaker J. 2015. Biochar suppresses $\mathrm{N} 2 \mathrm{O}$ emissions while maintaining $\mathrm{N}$ availability in a sandy loam soil. Soil Biology \& Biochemistry 81:178-185.

Case SDC, Niall PM, David SR, and Jeanette W. 2012. The effect of biochar addition on N2O and $\mathrm{CO} 2$ emissions from a sandy loam soil - The role of soil aeration. Soil Biology and Biochemistry 51:0-0.

Cayuela ML, van Zwieten L, Singh BP, Jeffery S, Roig A, and Sánchez-Monedero MA. 2014. Biochar's role in mitigating soil nitrous oxide emissions: A review and meta-analysis. Agriculture Ecosystems \& Environment 191:5-16.

Cheng W. 2020. Soil carbon and nitrogen dynamics by land use and management changes in East and Southeast Asian countries (soil C and N by LUMC). Soil Science \& Plant Nutrition.

Clairep m. 2005. Nonlinear response of $\mathrm{N} 2 \mathrm{O}$ flux to incremental fertilizer addition in a continuous maize (Zea mays L.) cropping system. Global Change Biology 11:17121719.

Clough TJ, Bertram JE, Ray JL, Condron LM, and Wells NS. 2010. Unweathered Wood Biochar Impact on Nitrous Oxide Emissions from a Bovine-Urine-Amended Pasture Soil. Soil Science Society of America Journal 74.

Clough TJ, Lanigan GJ, Klein CAMD, Samad MS, and Richards KG. 2017. Influence of soil moisture on codenitrification fluxes from a urea-affected pasture soil. Scientific Reports 7:Article number: 2185.

Dane, and Jacob H. 2002. [SSSA Book Series] Methods of Soil Analysis: Part 4 Physical Methods || 2.1 Bulk Density and Linear Extensibility. Soil Science Society of America Journal.

Dobbie KE, and Smith KA. 2001. The effects of temperature, water - filled pore space and land use on N2O emissions from an imperfectly drained gleysol. European Journal of Soil Science 52:667-673. 
567

568

569

570

571

572

573

574

575

576

577

578

579

580

581

582

583

584

585

586

587

588

589

590

591

592

593

594

595

596

597

598

599

600

601

602

603

604

605

606

607

608

609

610

611

612

613

614

615

616

Engel M, Notarnicola C, Endrizzi S, and Bertoldi G. 2017. Snow model sensitivity analysis to understand spatial and temporal snow dynamics in a high - elevation catchment. Hydrological Processes 31.

Feng Z, and Zhu L. 2017. Impact of biochar on soil N2O emissions under different biocharcarbon/fertilizer-nitrogen ratios at a constant moisture condition on a silt loam soil. Science of the Total Environment s 584-585:776-782.

Flechard CR, Ambus P, Skiba U, Rees RM, Hensen A, Amstel AV, Dasselaar PV, Soussana JF, Jones M, and Cliftonbrown J. 2007. Effects of climate and management intensity on nitrous oxide emissions in grassland systems across Europe. Agriculture, Ecosystems \& Environment 121:135-152.

Ghulam H, Diedrich S, Gerald M, Christoph M, and Claudia I. 2017. Biochar reduced nitrate leaching and improved soil moisture content without yield improvements in a four-year field study. Agriculture, Ecosystems \& Environment.

Goldberg SD, and Gebauer G. 2008. Drought turns a Central European Norway spruce forest soil from an N2O source to a transient N2O sink. Global Change Biology 15:850-860.

Granato D, Santos JS, Escher GB, Ferreira BL, and Maggio RM. 2018. Use of principal component analysis (PCA) and hierarchical cluster analysis ( $\mathrm{HCA}$ ) for multivariate association between bioactive compounds and functional properties in foods: A critical perspective. Trends in Food Science \& Technology 72:83-90.

Gul S, Whalen JK, Thomas BW, Sachdeva V, and Deng H. 2015. Physico-chemical properties and microbial responses in biochar-amended soils: Mechanisms and future directions. Agriculture Ecosystems \& Environment 206:46-59.

He Z, Mao J, and Han X. 2018. Non-parametric estimation of particle size distribution from spectral extinction data with PCA approach. Powder Technology 325:510-518.

Henrique NE, Maia CMBdF, Carvalho MTdM, and Madari BEk. 2015. Biochar: pyrogenic carbon for agricultural use-a critical review. Revista Brasileira De Ciência Do Solo 39:321-344.

Horák J, Kondrlová E, Igaz D, imansk V, and Jankowski M. 2017. Biochar and biochar with Nfertilizer affect soil N2O emission in Haplic Luvisol. Biologia 72.

Hu N, Wang B, Gu Z, Tao B, Zhang Z, Hu S, Zhu L, and Meng Y. 2016. Effects of different straw returning modes on greenhouse gas emissions and crop yields in a rice-wheat rotation system. Agriculture Ecosystems \& Environment 223:115-122.

Imaizumi M, and Kato K. 2018. PCA-based estimation for functional linear regression with functional responses. Journal of Multivariate Analysis 163:15-36.

Ji Y, Liu G, Jing M, Hua X, and Yagi K. 2012. Effect of controlled-release fertilizer on nitrous oxide emission from a winter wheat field. Nutrient Cycling in Agroecosystems 94:111122.

Joby M, and Mahanthesh B. 2019. Sensitivity analysis of radiative heat transfer in Casson and nano fluids under diffusion-thermo and heat absorption effects. European Physical Journal Plus 134.

Lan T, Han Y, Roelcke M, Nieder R, and Cai Z. 2013. Processes leading to N $2 \mathrm{O}$ and NO emissions from two different Chinese soils under different soil moisture contents. Plant and Soil 371.

Lei M, Ding W, and Cai Z. 2005. Long-term application of organic manure and nitrogen fertilizer on N2O emissions, soil quality and crop production in a sandy loam soil. Soil Biol Biochem 37:2037-2045.

Li GT, Zhao ZJ, and Huang YF. 2002. Effect of straw returning on soil nitrogen transformation. Plant Natrition and Fertilizen Science.

Liu D, Ding Z, Ali F, Kheir A, and Ibrahim O. 2021. Biochar and compost enhance soil quality and growth of roselle (Hibiscus sabdariffa L.) under saline conditions. Scientific Reports 11.

Peer) reviewing PDF | (2020:11:55062:2:0:NEW 29 May 2021) 
617

618

619

620

621

622

623

624

625

626

627

628

629

630

631

632

633

634

635

636

637

638

639

640

641

642

643

644

645

646

647

648

649

650

651

652

653

654

655

656

657

658

659

660

661

662

663

664

665

666

Lognoul M, Debacq A, Ligne AD, Dumont B, Manise T, Bodson B, Heinesch B, and Aubinet M. 2019. N 2 O flux short-term response to temperature and topsoil disturbance in a fertilized crop: An eddy covariance campaign. Agricultural and Forest Meteorology 271.

Macdonald LM, Farrell M, Zwieten LV, and Krull ES. 2014. Plant growth responses to biochar addition: an Australian soils perspective. Biology \& Fertility of Soils 50:1035-1045.

Major, Julie, Rondon, Marco, Molina, Diego, Riha, J S, Lehmann, and Johannes. 2012. Nutrient Leaching in a Colombian Savanna Oxisol Amended with Biochar. Journal of Environmental Quality 41.

Nanda S, Dalai AK, Berruti F, and Kozinski JA. 2016. Biochar as an Exceptional Bioresource for Energy, Agronomy, Carbon Sequestration, Activated Carbon and Specialty Materials. Waste \& Biomass Valorization 7:201-235.

Oki T. 2006. Global Hydrological Cycles and World Water Resources. Science 313:1068-1072.

Prado AD, Merino P, Estavillo JM, Pinto M, and González-Murua C. 2006. N2O and NO emissions from different $\mathrm{N}$ sources and under a range of soil water contents. Nutrient Cycling in Agroecosystems 74:229-243.

Qi D, Hui D, Wang J, Iwuozo S, Yu CL, Jima T, Smart D, Reddy C, Dennis S, and Hu S. 2015. Corn Yield and Soil Nitrous Oxide Emission under Different Fertilizer and Soil Management: A Three-Year Field Experiment in Middle Tennessee. Plos One 10:e0125406-.

Qu J, Akindolie MS, Feng Y, Jiang Z, Zhang G, Jiang Q, Deng F, Cao B, and Zhang Y. 2020. One-pot hydrothermal synthesis of $\mathrm{NaLa}(\mathrm{CO} 3) 2$ decorated magnetic biochar for efficient phosphate removal from water: Kinetics, isotherms, thermodynamics, mechanisms and reusability exploration. Chemical Engineering Journal 394.

Rajkovich S, Akio E, Kelly H, Charles H, Andrew RZ, and Johannes L. 2012. Corn growth and nitrogen nutrition after additions of biochars with varying properties to a temperate soil. Biology \& Fertility of Soils 48:271-284.

Saarnio S, Heimonen K, and Kettunen R. 2013. Biochar addition indirectly affects N2O emissions via soil moisture and plant N uptake. Soil Biology \& Biochemistry 58:99-106.

Schmidt U, Thöni H, and Kaupenjohann M. 2000. Using a boundary line approach to analyze N2O flux data from agricultural soils. Nutrient Cycling in Agroecosystems 57.

Sharmistha, PAL, Petra, and MARSCHNER. 2016. Soil Respiration, Microbial Biomass C and N Availability in a Sandy Soil Amended with Clay and Residue Mixtures. Pedosphere:643651.

Shcherbak I, and Robertson GP. 2019. Nitrous Oxide (N2O) Emissions from Subsurface Soils of Agricultural Ecosystems. Ecosystems.

Stacklies W, Redestig H, Scholz M, Walther D, and Selbig J. 2007. pcaMethods - a bioconductor package providing PCA methods for incomplete data. Bioinformatics 23:1164-1167.

Stewart CE, Zheng J, Botte J, and Cotrufo MF. 2013. Co-generated fast pyrolysis biochar mitigates green-house gas emissions and increases carbon sequestration in temperate soils. Global Change Biology Bioenergy 5:153-164.

Takakai F, Kominami Y, Ohno S, and Nagata O. 2019. Effect of the long-term application of organic matter on soil carbon accumulation and GHG emissions from a rice paddy field in a cool-temperate region, Japan. -I. Comparison of rice straw and rice straw compost. Soil Science \& Plant Nutrition.

Tan J, Cui Y, and Luo Y. 2017. Assessment of uncertainty and sensitivity analyses for ORYZA model under different ranges of parameter variation. European Journal of Agronomy 91:54-62.

Vico A, Sáez J, Pérez-Murcia MD, Martinez-Tomé J, Andreu-Rodríguez J, Agulló E, Bustamante MA, Sanz-Cobena A, and Moral R. 2020. Production of spinach in intensive

Peer) reviewing PDF | (2020:11:55062:2:0:NEW 29 May 2021) 
667

668

669

670

671

672

673

674

675

676

677

678

679

680

681

682

683

684

685

686

687

688

689

690

691

692

693

694

695

696

697

698

699

700

701

702
Mediterranean horticultural systems can be sustained by organic-based fertilizers

without yield penalties and with low environmental impacts. Agricultural Systems 178.

Wu D, Dong W, Oenema O, Wang Y, Trebs I, and Hu C. 2013. N2O consumption by lownitrogen soil and its regulation by water and oxygen. Soil Biology \& Biochemistry 60:165172.

Yao Z, Yan G, Zheng X, Rui W, Liu C, and Butterbach-Bahl K. 2017. Straw return reduces yieldscaled $\mathrm{N} 2 \mathrm{O}$ plus $\mathrm{NO}$ emissions from annual winter wheat-based cropping systems in the North China Plain. Science of the Total Environment 590-591:174-185.

Zhang A, Cui L, Pan G, Li L, Hussain Q, Zhang X, Zheng J, and Crowley D. 2010. Effect of biochar amendment on yield and methane and nitrous oxide emissions from a rice paddy from Tai Lake plain, China. Agriculture, Ecosystems and Environment 139.

Zhang Q, Wang Y, Wu Y, Wang X, Du Z, Liu X, and Song J. 2013. Effects of Biochar Amendment on Soil Thermal Conductivity, Reflectance, and Temperature. Soil Science Society of America Journal 77:1478.

Zhang W, Cheng W, Meng J, Jin L, Wei G, and ZHao H. 2019a. Study of Straw-Biochar on Utilization Potential, Industry Model and Developing Strategy in Northeast China. Scientia Agricultura Sinica 52:2406-2424.

Zhang X, Xia J, Pu J, Cai C, Tyson GW, Yuan Z, and Hu S. 2019b. Biochar-Mediated Anaerobic Oxidation of Methane. Environmental Ence \& Technology 53:6660-6668.

Zhao X, Wang J, Wang S, and Xing G. 2014. Successive straw biochar application as a strategy to sequester carbon and improve fertility: A pot experiment with two rice/wheat rotations in paddy soil. Plant \& Soil 378:279-294.

Zhao Z, Han X, Shi Y, Wu W, and Meng F. 2016. Effect of nitrification and urease inhibitor on carbon sequestration and greenhouse gas emissions in winter wheat and summer maize rotation system in North China.

Zhou Y, Zhang Y, Tian D, and Mu Y. 2017. The influence of straw returning on N2O emissions from a maize-wheat field in the North China Plain. Science of the Total Environment s 584-585:935-941.

Zou J, Huang Y, Lu Y, Zheng X, and Wang Y. 2005. Direct emission factor for N2O from ricewinter wheat rotation systems in southeast China. Atmospheric Environment 39:47554765.

Zwieten LV, Singh BP, Kimber S, Murphy DV, Macdonald LM, Rust J, and Morris S. 2014. An incubation study investigating the mechanisms that impact $\mathrm{N} 2 \mathrm{O}$ flux from soil following biochar application. Agriculture Ecosystems \& Environment 191:53-62. 
Figure 1

Figure 1: The soil water content for each treatment in the depth of $10 \mathrm{~cm}, 20 \mathrm{~cm}, 40$ $\mathrm{cm}, 60 \mathrm{~cm}$, and $80 \mathrm{~cm}$ during 2019-2020 is presented
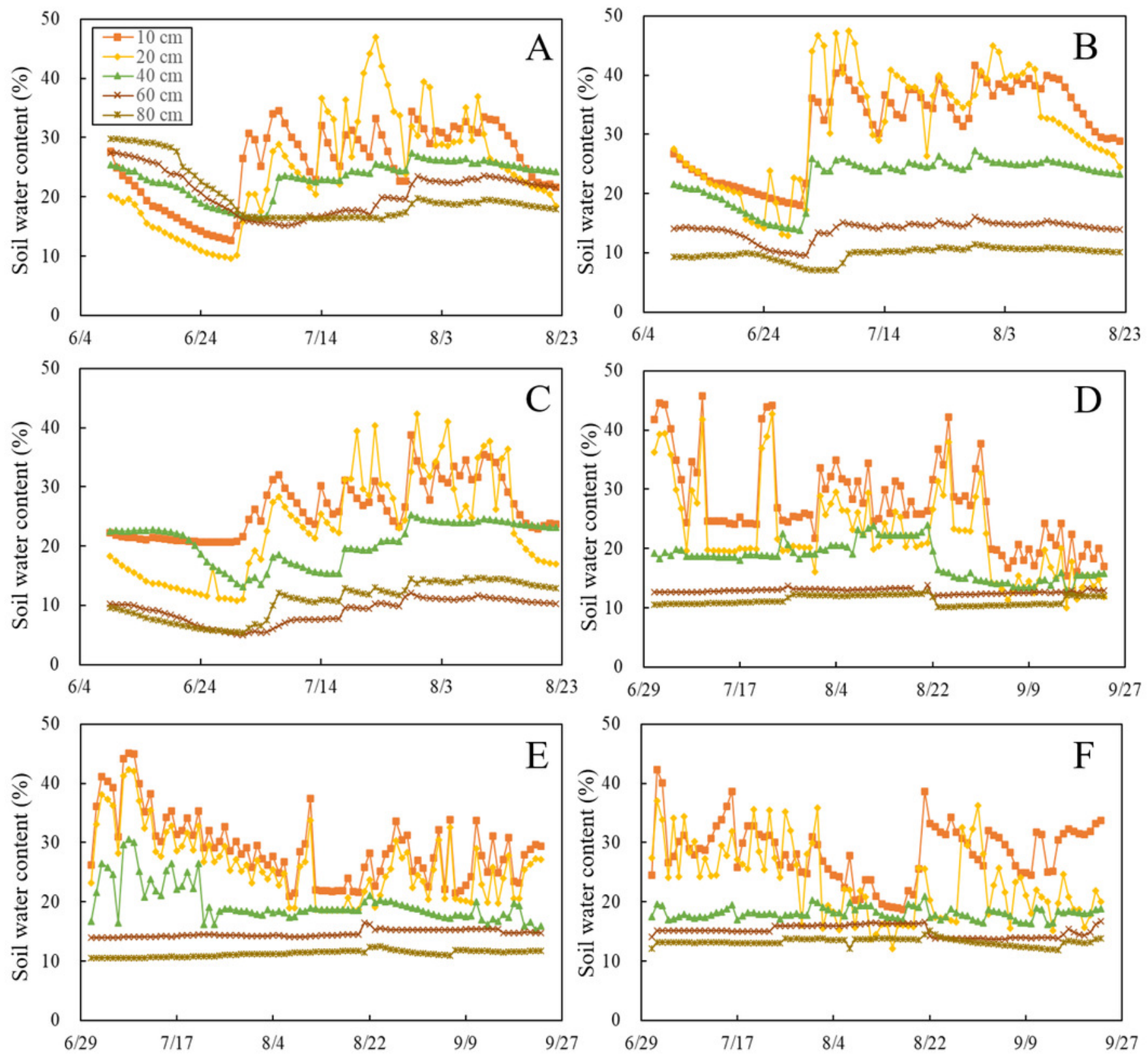
Figure 2

Figure 2: The soil temperature for each treatment in the depth of $10 \mathrm{~cm}, 20 \mathrm{~cm}, 40 \mathrm{~cm}$, $60 \mathrm{~cm}$, and $80 \mathrm{~cm}$ during 2019-2020 is presented
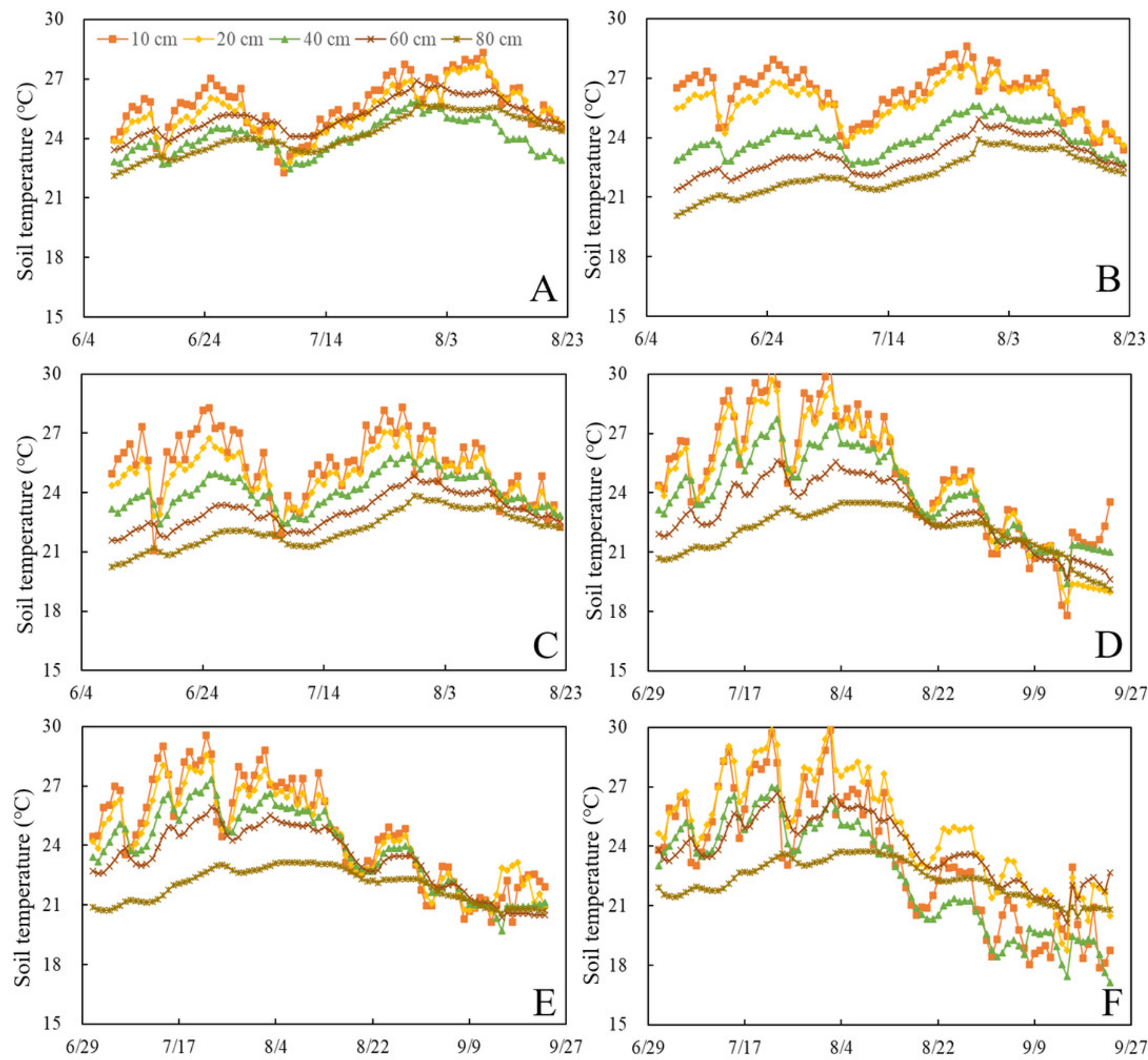
Figure 3

Figure 3: $\mathrm{N}_{2} \mathrm{O}$ emissions in the maize growth stage is presented. $(A)$ and $(B)$ show the $\mathrm{N}_{2} \mathrm{O}$ emissions in 2019 and 2020, respectively
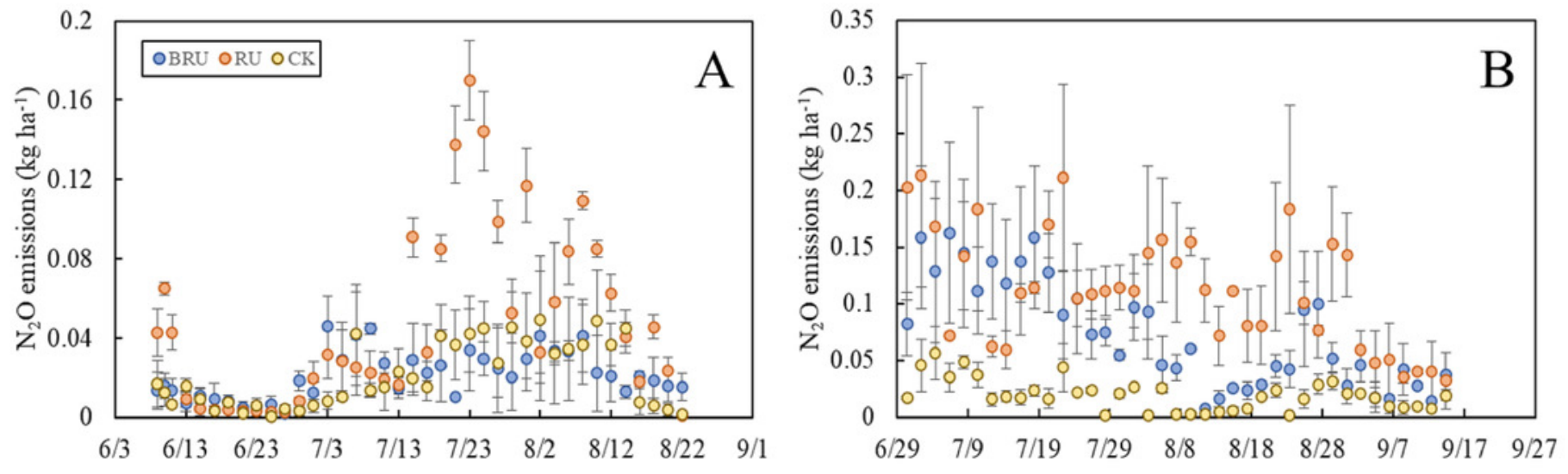
Figure 4

Figure 4: The fitting about WFPS, soil temperature, and $\mathrm{N}_{2} \mathrm{O}$ emissions based on MNF-DR analysis for each treatment during 2019-2020 is presented 

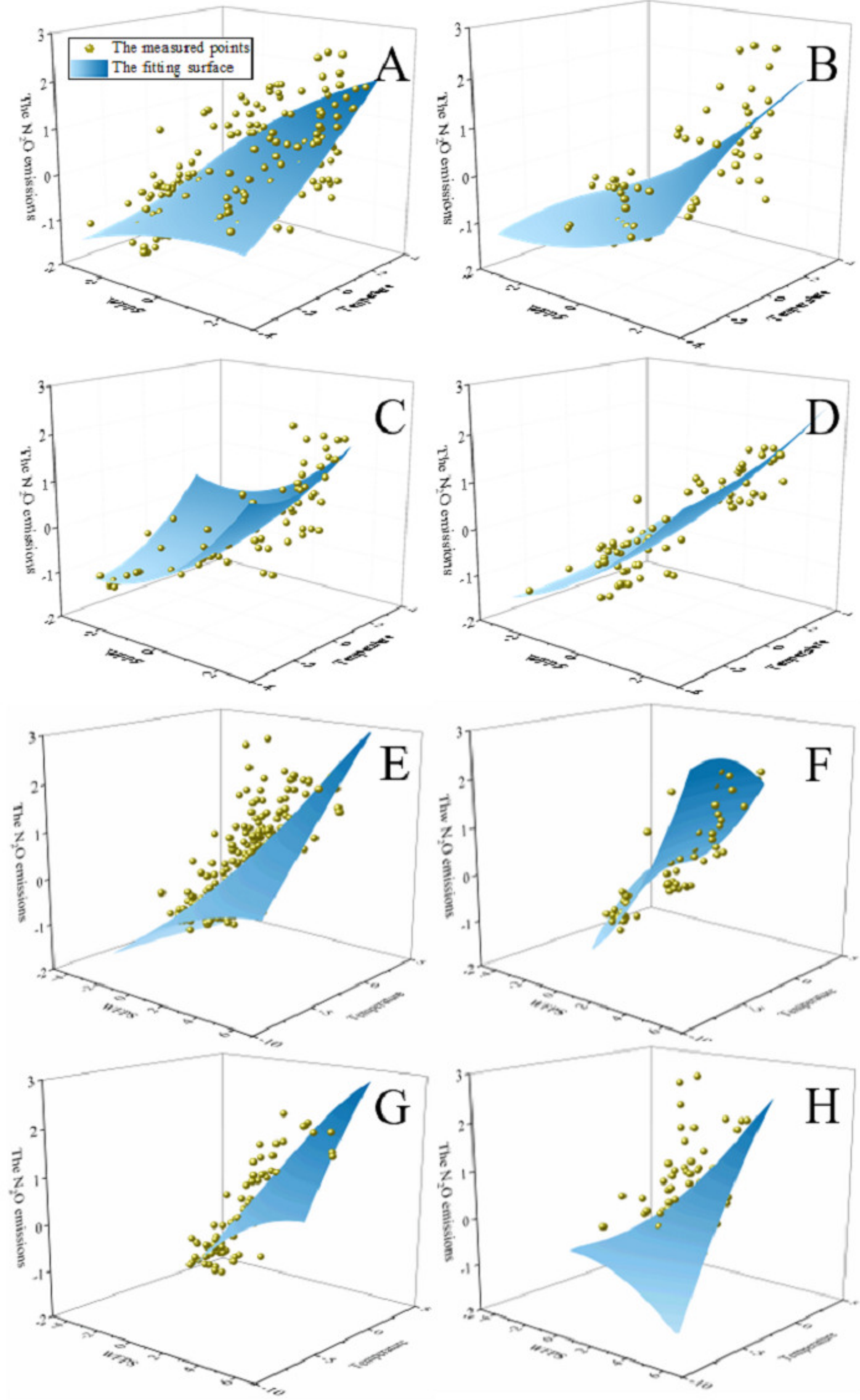
Figure 5

Figure 5: The fitting about WFPS and $\mathrm{N}_{2} \mathrm{O}$ emissions based on the exponential model for each treatment during 2019-2020 is presented 

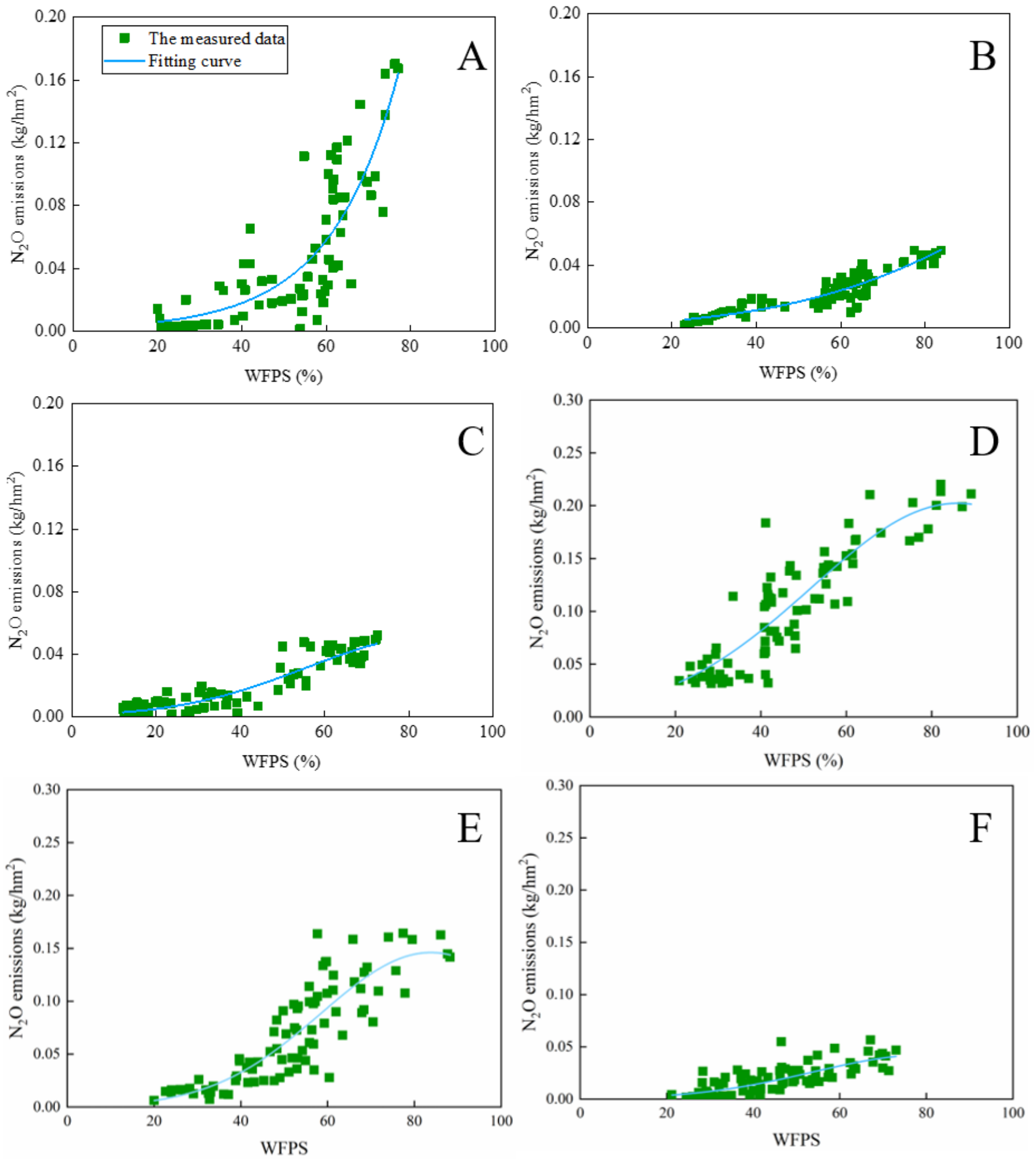
Figure 6

Determinants of soil $\mathrm{N}_{2} \mathrm{O}$ emissions

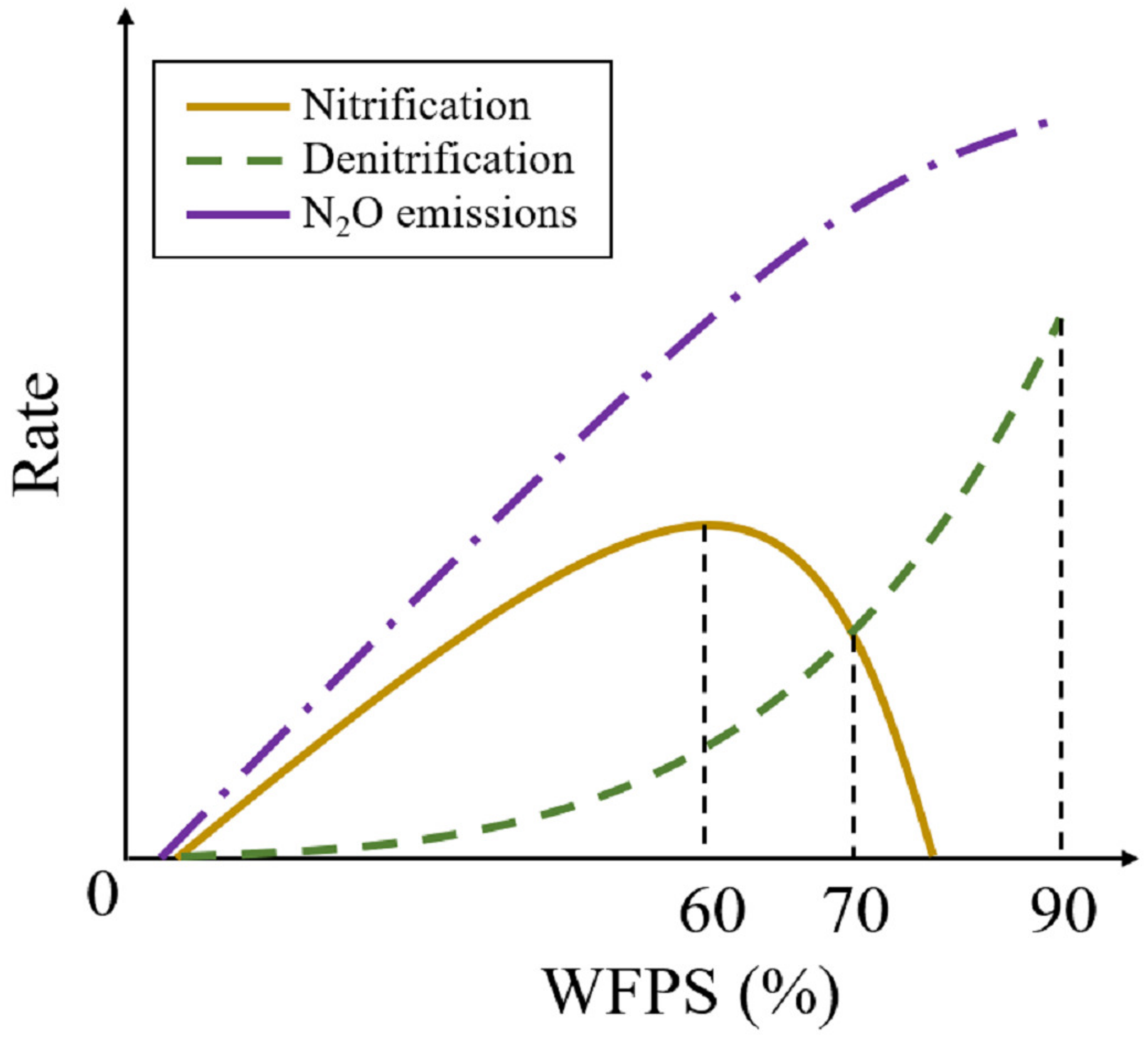




\section{Table 1 (on next page)}

Correlation among the soil water content, temperature, and $\mathrm{N}_{2} \mathrm{O}$ emissions 
1

2

3

4

Table 1 Correlation among the soil water content, temperature, and $\mathrm{N}_{2} \mathrm{O}$ emissions.

\begin{tabular}{|c|c|c|c|c|c|c|}
\hline & & \multicolumn{5}{|c|}{ Soil water content in different depth } \\
\hline & & $10 \mathrm{~cm}$ & $20 \mathrm{~cm}$ & $40 \mathrm{~cm}$ & $60 \mathrm{~cm}$ & $80 \mathrm{~cm}$ \\
\hline & RU & $0.564 * *$ & $0.761 * *$ & $0.465 * *$ & 0.097 & $-0.310 * *$ \\
\hline \multirow[t]{3}{*}{2019} & BRU & $0.767 * *$ & $0.883 * *$ & $0.704 * *$ & $0.427 * *$ & 0.008 \\
\hline & CK & $0.834 * *$ & $0.906 * *$ & $0.701 * *$ & $0.557 * *$ & $0.341 * *$ \\
\hline & RU & $0.886^{* *}$ & $0.881 * *$ & $0.423 * *$ & 0.011 & $-0.120 * *$ \\
\hline \multirow[t]{5}{*}{2020} & BRU & $0.783 * *$ & $0.805 * *$ & $0.641 * *$ & $-0.514 * *$ & $-0.747 * *$ \\
\hline & CK & $0.389 * *$ & $0.775 * *$ & $0.300 * *$ & -0.092 & -0.083 \\
\hline & & \multicolumn{5}{|c|}{ Soil temperature in different depth } \\
\hline & & $10 \mathrm{~cm}$ & $20 \mathrm{~cm}$ & $40 \mathrm{~cm}$ & $60 \mathrm{~cm}$ & $80 \mathrm{~cm}$ \\
\hline & RU & $0.377 * *$ & $0.437 * *$ & $0.502 * *$ & $0.494 * *$ & $0.438^{* *}$ \\
\hline \multirow[t]{3}{*}{2019} & BRU & $0.667 * *$ & $0.751 * *$ & $0.309 * *$ & $0.451 * *$ & $0.478 * *$ \\
\hline & $\mathrm{CK}$ & 0.087 & $0.274 *$ & $0.529 * *$ & $0.666^{* *}$ & $0.670 * *$ \\
\hline & RU & $0.496 * *$ & $0.551 * *$ & $0.501 * *$ & $0.494 * *$ & $0.380 * *$ \\
\hline \multirow[t]{2}{*}{2020} & BRU & $0.568 * *$ & $0.546 * *$ & $0.512 * *$ & $0.403 * *$ & -0.075 \\
\hline & CK & $0.297 * *$ & $0.215^{*}$ & $0.327 * *$ & 0.100 & -0.076 \\
\hline
\end{tabular}

*, ** Significant at $\mathrm{P}<0.05,0.01$ levels, respectively (least significant difference test) 
Table 2 (on next page)

Coefficient of PC1 


\begin{tabular}{ccccccc}
\hline & $\mathrm{a}$ & $\mathrm{b}$ & $\mathrm{c}$ & $\mathrm{d}$ & $\mathrm{e}$ & $\mathrm{f}$ \\
\hline 2019 & 0.610 & 0.537 & 0.583 & 0.596 & 0.607 & 0.526 \\
\hline 2020 & 0.622 & 0.615 & 0.486 & 0.585 & 0.573 & 0.573 \\
\hline
\end{tabular}

5 The coefficients above represents using MNF-DR analyzed the total observed points (RU+BRU+CK).

6

7

8 
Table 3 (on next page)

Coefficient of multiple nonlinear regression 
1

2

3

\begin{tabular}{ccccccccccc}
\hline \multirow{2}{*}{2019} & Treatment & $\mathrm{z}_{0}$ & $\mathrm{k} 1$ & $\mathrm{k} 2$ & $\mathrm{k} 3$ & $\mathrm{k} 4$ & $\mathrm{k} 5$ & $\mathrm{R}$ & $\mathrm{F}$ \\
& Total & 0.023 & 0.276 & 0.301 & -0.030 & 0.014 & 0.049 & 0.51 & $39.37^{*}$ \\
& $\mathrm{RU}$ & -0.046 & 0.433 & 0.196 & 0.039 & -0.022 & 0.058 & 0.61 & $19.91^{*}$ \\
& $\mathrm{BRU}$ & -0.309 & 0.480 & 0.203 & 0.093 & 0.061 & -0.044 & 0.73 & $33.34^{*}$ \\
& $\mathrm{CK}$ & -0.186 & 0.529 & 0.146 & 0.054 & 0.017 & 0.015 & 0.84 & $65.22^{*}$ \\
\hline \multirow{2}{*}{2020} & Total & 0.008 & 0.482 & 0.109 & -0.016 & -0.002 & 0.039 & 0.60 & $64.26^{*}$ \\
& RU & 0.022 & 0.492 & 0.056 & 0.065 & -0.031 & -0.054 & 0.80 & $55.30^{*}$ \\
& BRU & 0.098 & 0.490 & 0.208 & -0.003 & -0.015 & 0.045 & 0.75 & $43.45^{*}$ \\
& $\mathrm{CK}$ & 0.056 & 0.398 & 0.097 & -0.030 & -0.018 & 0.098 & 0.31 & 7.26 \\
\hline
\end{tabular}

$4 *$, ** Significant at $\mathrm{P}<0.05,0.01$ levels, respectively (least significant difference test); 'Total' represents fitting RU and BRU and 5 CK treatment simultaneously; ' $\mathrm{F}$ ' represents $\mathrm{F}$ value at significance analysis.
6 


\section{Table 4 (on next page)}

$\mathrm{N}_{2} \mathrm{O}$ emission observations and MNF-DR analysis during the growing period of maize 
Table 4 Coefficients, determinative factor, and $\mathrm{F}$ value of Eq. (9)

\begin{tabular}{ccccccc}
\hline & Treatment & $\mathrm{a}$ & $\mathrm{b}$ & $\mathrm{c}$ & $\mathrm{R}^{2}$ & $\mathrm{~F}$ value \\
\hline \multirow{2}{*}{2019} & RU & $-6.436 * 10^{-5}$ & 0.052 & -6.218 & 0.70 & $153.90 * *$ \\
& BRU & $-1.266 * 10^{-4}$ & 0.053 & -6.365 & 0.81 & $535.23 * *$ \\
& $\mathrm{CK}$ & $5.251 * 10^{-4}$ & 0.091 & -6.898 & 0.85 & $411.30 * *$ \\
\hline \multirow{2}{*}{2020} & RU & $-4.282 * 10^{-4}$ & 0.074 & -4.774 & 0.78 & $587.31 * *$ \\
& BRU & $-7.811 * 10^{-4}$ & 0.131 & -7.411 & 0.74 & $320.72 * *$ \\
& CK & $-6.791 * 10^{-4}$ & 0.110 & -7.594 & 0.59 & $165.93 * *$ \\
\hline
\end{tabular}

$6 *, * *$ Significant at $\mathrm{P}<0.05,0.01$ levels, respectively (least significant difference test)

7

8

9 